Journal of Social Sciences 7 (3): 326-330, 2011

ISSN 1549-3652

(C) 2011 Science Publications

\title{
Strategic Development Project for Specific Activities of "the Sports for all" in Caras-Severin County
}

\author{
Dumitru Evuleț Colibaba, Liliana Dacica and Andrade Bichescu \\ Department of Physical Education and Sports, \\ University of Piteşti and University "Eftimie Murgu" Reşița, 110225, Romania
}

\begin{abstract}
Problem statement: The study elaborates and practically applies a strategic development project for specific activities of the sports for all which proposes as distinct aims the prevailing promotion of "the sport disciplines demanded by the client age and especially the continuous increase of the citizens' life quality in Caraş-Severin County. Approach The analysis and identification of major problems which animate the organization and evolution of activities specific to the sports for all. Results The increase of the number of persons who systematically take part in specific activities for the sports for all" by $10 \%$ in 2010 and by $20 \%$ in 2011, compared to 2008. Conclusions: The conclusion of the opinion survey regarding attitude of the client age, population towards activities specific to the sports for all, needs promotion at DJS Caraş-Severin level of a strategic and participative management which needs some major changes.
\end{abstract}

Key words: Client age, body structure, avoiding monotony, physical education, stress solicitations, swot analysis, peste analysis, human personality, strategic development

\section{INTRODUCTION}

The Sports for all (the spare time Sports) is the generically expression which implies a multitude of activities especially metric (Sporting) ones which demand to be practiced as a compensatory answer to the noxious effects (sedentariness, the technicians of some metric activities, stress conditions,) of post-modern society. The study of (Seals et al., 2008). Follow the same idea, to identify best practices for designing and creating applications for a senior population. Khan (2009) says that professional education is the principle means of the developing the human resource. Under these conditions, it was observed that the specific activities of Sports for all exert on human personality the following categories of functions:

- Biometric (health, physical state, recuperation, body structure, mortality)

- Psycho-social (motivations and needs such as the need for movement, for relaxation, for relief, entertainment enlightenment, (self) education)

- Social (socialization, instincts abatement, avoiding monotony, conflicts abatement)

In contrast with the present situation in other developed countries of EU, (Bacanu, 1997; Colibaba,
2007; Frincu, 2003;), says that generally in Romania and particularly in Caraş-Severin County, these activities are still poorly popularized and turned into beneficent aims. This deficiency can be corrected with the help of a strategic project of continuous improvement of these activities which should effectively contribute to the increase of "life quality" identifiable by the 4 distinct elements: The environment (the relationship manenvironment), social background (physical education and social relations), the professional background and the family background.

\section{The project explanation:}

- A chance to effectively and efficiently acquire and capitalize the (material, financial, human, information, spare time budget) resources which exist in the county in order to fully exert the specific functions of these activities on the human personality

- The possibility to respect more the motivations and the needs of the interest groups and of the social client age of Caraş-Severin county

- The liberty to resort to diverse financial sources, to natural material resources, complex geographical and human resources in relation to the needs, solicitations and possibilities of each social category

Corresponding Author: Dumitru Evuleț Colibaba, Department of Physical Education and Sport,

University of Piteşti and University "Eftimie Murgu” Reşița, 110225, Romania 
- The necessity to educate the citizens' life and conduct conception regarding the capitalization of the spare time budget in purposefulness (health, culture, relaxation, compensating the stress solicitations)

\section{The importance of the project:}

- Multiple determination-having in view: The strategic development aims, the concrete conditions of activity development, the weight of practicing some activities, the development level of the activity on local level, the resources available or susceptible of being acquired

- Strategic value-an instrument which provides the far-sightedness of a 3/4 years horizon, with clear objectives, orientations and directions for the forms of practicing looser activities having the aim of involving the largest number of citizens

- Has a situational character-i.e., the development programs will be elaborated starting from a diagnosis analysis of the internal and external background (SWOT and PESTE) and the optimization of the continuous development conditions of Sports activities under examination

- Has a structure which aims two distinct components

- Strategic which states the mission, targets and finalities of each program

- Operational which supposes the practical application and their continuous correction by feed-back

- Main beneficiary: All the interest groups and all the citizens' categories in Caraş-Severin county

\section{MATERIALS AND METHODS}

The aim of the research: The analysis and the identification of major problems which animate the organization and evolution of the activities specific to the Sports for all, exerted at county level, having in view the elaboration and monitoring of some strategic development programs which propose as distinct aims the promotion of the Sports disciplines claimed by the client age population and especially the continuous increase of the citizens' life quality in Caraş-Severin county.

\section{The objectives of the research:}

- The Actual Stage Ascertainment of the knowledge and research of the theme under discussion
- The identification of the deficient problems involved in the theme of the research program

- Preliminary study regarding the quality and efficiency of activities specific to the Sports for all lat county level

- Inquiry and opinion survey on the problems of major importance, of the role and functions which it exerts on the forms of practicing Sports for all on local level

- Inventorying all forms of activity specific to the Sports for all in the Caraş-Severin County and the number of participants

- The identification of the situational character of the independent variables recorded in the research assumptions, as follows:

- The use of the SWOT diagnosis analysis in order to establish the problems specific for the internal and external background of D.J.S Caraş-Severin

- The structural and procedural organization of the D.S.J.'s entire activity by highlighting the organizations and the persons responsible for the organization and management of the activities specific to the Sports for all

- The identification of the factors which influence the external background: Local relationships, socio-economical conditions, finances, natural geographical environment, sponsors, influence factors, psycho-social field

- The analysis and solving of problems issued from the SWOT analysis by applying the methods specific to the managerial science: The logical frame method; the PESTE analysis; the GANTT diagram

The managerial strategic project's preparation and elaboration of the continuous improvement of the activities specific to the Sports for all are:

- The ascertainment of the strategic targets or the purpose of the project

- $\quad$ Stating the objectives, the aimed results on fields and the managerial functional organisations

- The identification of the available resources and their effective and efficient distribution

- Conceiving the project

- Packing (the adequate display of the project)

The implementation, monitoring and reporting the results obtained:

- The elaboration of the operational plans on time units 
- The mobilization of resources for each objective proposed

- Promotional activities to stimulate the participants

- The project marketing

- The monitoring and the ascertainment of the distribution process

- The identification of the problems connected to their implementation and solving

- Corrections and modifications of the project

- The risks evaluation and solving alternatives

- The evaluation of the project

- The results obtained and their interpretation

The assumptions of the research: The experimental demarche is pointed towards the control and demonstration of the following assumptions:

- If we will achieve a detailed analysis of the market requirements (the activities and services pretended by the client age population) as well as the organising and evolving system of the activities specific to the "Sports for all then, we can elaborate a strategic project of these activities continuous development with well-defined finalities, which should effectively and efficiently contribute to the improvement of the citizens' life quality in caraş-severin county

- The activities specific to the "Sports for all" could be sensibly improved if in their organisation and management, we will well implement the managerial functions, such as: Forecast, organisation, coordination, management (execution, engagement), inspection, control, evaluation, guidance- monitoring

\section{Research methods and techniques used:}

- Psycho-pedagogic methods: Direct and indirect observation; opinion survey and inquiry among the client age population, experimental and statisticalmathematical inquiry, graphical representation

- Specific methods for the managerial science: The analysis of the activities developed in different managerial organisations and departments of DJS Caraş-Severin, the SWOT, PESTE, CADRULUI LOGIC, GANTT diagnosis analysis

Material basis: swimming pool; skating-rink; 5 fitness rooms; 35 school Sports courses; 27 school Sports rooms; polyvalent hall; 13 stadiums; 2 synthetically courses; 5 tennis courts.
Sports disciplines and practiced activities: mountainclimbing, cycling, enduro motoring, cross, jogging, aerobics, fitness, chess, tennis, table tennis, aqua gym, football-tennis, volleyball, minifootball, hiking, ski, speleology, tourist orientation, swimming, street ball, roller-skates, baby-gym.

This inventory allowed us to establish the following finalities of the strategic project:

\section{RESULTS}

The results obtained up to the present: The scientific demarche developed by us is in its preliminary phase in which the following activities were achieved: A. (Table 1): Inventorying the available resources for the development of the specific activities for "the Sports for all" at county level.

- The increase of the number of persons who systematically take part in specific activities for the "Sports for all"-by 10\% in 2010 and by $20 \%$ in 2011, compared to 2008

- The distribution of age and studies of the persons engaged in the activity are presented in the Table 2 and 3

- The release of some promotional activities in order to capitalize the present natural geographical environment

- If the program "the Sports for all" is known: $38 \%$ little known

- From the 626 persons questioned, 51\% systematically practise such activities as jogging, fitness, aerobics

- There are not enough competitions organised which could engage all the citizens' categories: $59 \%$ of the questioned persons

- To educate a habit of practising different Sports and physical education must be achieved especially by the school teachers $(60 \%)$

Table 1: Resources available for the development of the project

\begin{tabular}{lllll}
\hline Resources & 2008 & 2009 & 2010 & 2011 \\
\hline Finances planned & 276520 & 305470 & & \\
Spent finances & 231000 & 264000 & & \\
Spent time & $381 \mathrm{~h}$ & $432 \mathrm{~h}$ & & \\
Profits & $5 \%$ & $7 \%$ & $10 \%$ & $15 \%$ \\
Number of participants & 29134 & 31030 & $10 \%$ & \\
Compared to 2008 & $20 \%$ & & & \\
Compared to 2008 & $*$ & $*$ & $*$ & $*$ \\
Material basis & $* *$ & $* *$ & $* *$ & $* *$ \\
$\quad$ Sports disciplines & $* *$ & & & \\
and motric activities & & & & \\
\hline
\end{tabular}


- Very few citizens weekly allot an optimal time for Sports activities

- Family Sports is very little practised (68\% do not practise it)

- To practise the activities specific to the "Sports for all" is a good opportunity to identify the talented elements $(92 \%)$

- The order of the clientage population's preferences: handball (24\%), football (21\%), swimming (17\%), basketball (11\%), table tennis (9\%), football-tennis (8\%), volleyball (5\%), badminton (4\%)

- The spare time activities should be more supported by the state organisations and institutions ( $81 \%)$

- The natural-geographical resources are not capitalized in order to practise winter Sports, tourism, hiking, swimming (63\%)

- Distribution on group ages of the participants in the inquiry and Percentage of the study level of the participants in the inquiry is presented in the Fig. 1 and 2

Table 2: Distribution on group ages of the participants in the inquiry

\begin{tabular}{llll}
\hline Age & $10-14$ years & $9.22 \%$ & 58 \\
15-19 years & $11.31 \%$ & 71 \\
20-24 years & $11.54 \%$ & 72 \\
25-34 years & $18.91 \%$ & 118 \\
35-49 years & $25.58 \%$ & 160 \\
& $50-64$ years & $23.44 \%$ & 147 \\
\hline
\end{tabular}

\begin{tabular}{llll}
\multicolumn{3}{l}{ Table 3: Level of studies of the participantsin the inquiry } \\
\hline Studies & Gymnasium & $49 \%$ & 305 \\
& Professional & $1 \%$ & 9 \\
& High-school & $30 \%$ & 188 \\
& University & $18 \%$ & 115 \\
& Post-university & $1 \%$ & 9 \\
\hline
\end{tabular}

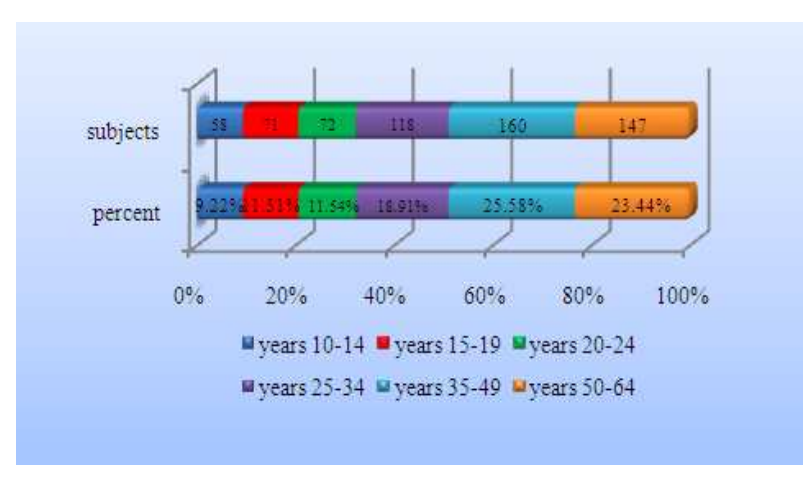

Fig. 1: Distribution on group ages of the participants in the inquiry

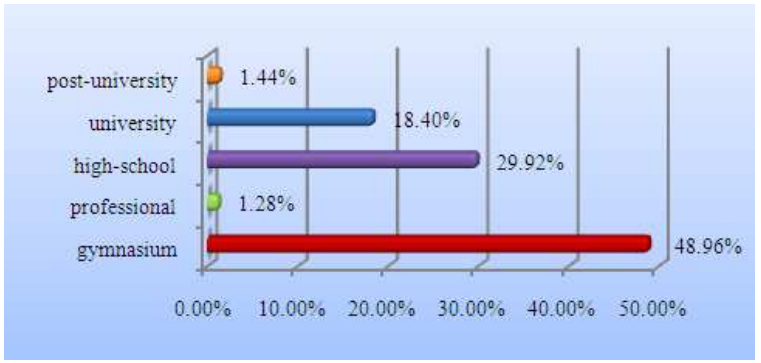

Fig. 2: Percentage of the study level of the participants in the inquiry

\section{DISCUSSION}

- Focus on specific activities for the "Sports for all" towards distinct finalities such as: Maintaining wellness and fitness, activities meant for spending spare time, Sports and activities with relaxing features for the unfolded professional activity, family Sports and activities accessible for seniors

- Full capitalization and operation of the material basis made available by a judicious activity of management and administration.

- A percentage of $98 \%$ from the questioned persons agree that the activities specific to the "Sports for all" have sanogenic benefits

- The activities specific to the "Sports for all" have a beneficent effect on all the educational dimensions and especially on the new educations such as: Ecological, social integrative education, education for democracy

\section{CONCLUSION}

The conclusion of the opinion survey regarding the attitude of the client age population towards the activities specific to the Sports for all (sample 626). From this survey, we note the following statistical data:

Partial conclusions and measures which must be included in the strategic managerial project: Practical application of the development project to the specific activities of the "Sports for all" needs promotion at DJS Caraş-Severin level of a strategic and participative management which needs some major changes regarding the following independent variables:

- The organisational, identified by 7 known elements: 1- structure, 2 - strategy; 3 qualifications, abilities; 4 - systems; 5 - people; 6 style; 7 - high level aims 
- The organisational behaviour-people's attitudes and behaviour in the information groups: The executive staff, the staff of committees and colleges, the volunteer personnel

- The procedural and structural organisation of the Sports Direction of the County;

- Functional and logistic structures: Financial, material basis, maintenance, tranSports, equipment, scientific assistance (medical, psychological, methodological)

- The development at Caraş-Severin level of a Sportsing Education Committee, an organisation within the Sports Direction of Caraş-Severin County which should ensure the coordination of the National Program "Sports for all" in partnership with the Caraş-Severin County association "Sports for All"

- To give a logistic support in the activity development of the Caraş-Severin County Association "Sports for All" and achieving partnerships of this Sports structure with other county associations on different Sports

- The development and support of the diverse continuous practice of physical and Sports activities involving the authorities of the local public administration, especially at rural level in Caraş-Severin county
- The promotional activities and the public's free access to the Sports complex built from public funds in the framework of a well-defined program in Caraş-Severin County

- Achieving some special programs for tourist activities combined with the practice of cultural and Sports activities: Winter Sports, nautical Sports, equestrian Sports, mountain climbing, motoring, cycle-tourism and others at county level

\section{REFERANCES}

Bacanu, B., 1997. Management strategic. Editura Teora, Bucureşti.

Colibaba, E.D., 2007. Praxiologia Și Proiectarea Curriculară in Educație Fizică Şi Sports. Editura Universităţii Craiova.

Seals, C.D., W. Moses, J. Nyagwencha, A. Martin and K. Clanton et al., 2008. Life long learning: seniors in second life continuum. J. Comput. Sci., 4: 10641070. DOI: $10.3844 /$ jessp.2008.1064.1070

Frincu, E., 2003. Managementul Activității Sportsive. Editura Ex, Ponto, Constanța.

Khan, Z.N., 2009. Cognitive and non-cognitive characteristics as determinants of success in professional courses at undergraduate stage. J. Soc. Sci., 5: 212-215. 